\title{
Geochemical and microbiological features of cryoconite, sampled from glaciers of the Central Caucasus region (Kabardino-Balkarian republic, Russia)
}

\author{
Evgeny Abakumov ${ }^{1, *}$, Vyacheslav Polyakov ${ }^{1}$, Ivan Kushnov ${ }^{1}$, and Rustam Tembotov ${ }^{2}$ \\ ${ }^{1}$ Saint Petersburg State University, Department of Applied Ecology, 199178 16-th line V. O. 29, Saint Petersburg, Russia \\ ${ }^{2}$ Tembotov Institute of Ecology of Mountain Territories Russian Academy of Sciences, 360051 I. Armand Street 37a, Nalchik, \\ Russia
}

\begin{abstract}
Determination of geochemical and microbiological properties of the cryoconite, related types of sediments and periglacial soils is essential to investigate impact of glaciers on terrains development at the Central Caucasus region. The studied sediments were sampled at the Garabashi and Skhelda glaciers as well as in vertical sections of local soils at the Baksan gorge. Sampled materials were investigated in terms of physicochemical parameters and nutritional state. The trace elements concentrations $(\mathrm{Cu}, \mathrm{Pb}, \mathrm{Zn}, \mathrm{Ni}$, $\mathrm{Cd}$ ) were also evaluated in samples selected. The data obtained shows much higher content of organic carbon in soils (up to $7.82 \%$ ) in comparison with cryoconite (max. 1.63\%) due to the effect of superficial vegetation cover, however, rates of microbial activity were similar between some samples of sediments and soils. The analysis of the particle size distribution shows a similarity of the studied materials: in almost all samples, there is a dominance of the sand fraction. Cryoconite sediments on both of the abovementioned glaciers are found as enriched with phosphorus, essential values of potassium $(298 \mathrm{mg} / \mathrm{kg}$ in $\mathrm{K}_{2} \mathrm{O}$ units) and ammonium nitrogen ( $\mathrm{N}^{-\mathrm{NH}_{4}}$ - max. $247 \mathrm{mg} * \mathrm{~kg}$ ) are identified at Garabashi glacier which could be a result of long-distant transfer and anthropogenic activity. The highest content among trace elements was identified for $\mathrm{Zn}(62 \mathrm{mg} * \mathrm{~kg}$ for cryoconite and $60.5 \mathrm{mg} * \mathrm{~kg}$ for soils), the most contaminated materials were sediments from Garabashi glacier and Entisols, up to moderate level, which is mostly associated with anthropogenic activity. Thus, development of tourism in the Central Caucasus, which is mostly associated with construction and transport, affects the pollution status of supraglacial sediments and periglacial soils as well as their agrochemical and microbiological features.
\end{abstract}

\section{Introduction}

Nowadays, degradation of glaciers is an active process in mountain areas of the World. In the Central Caucasus mountain region deglaciation is usually associated with presence of cryoconite. In this term «cryo» means ice and «conite» means dust [1]. Cryoconite are widespread among the glaciers in different Earth regions. They can be found in holes or dispersed over the surface of the glaciers at high latitudes as well as at the mountain regions all over the world, even at the surface of debriscovered glaciers [2, 3]. Cryoconite is abundant in supraglacial environment dark-colored granular sediment, which represents a mixture of mineral particles, organic matter and black carbon [4]. Usually it is transferred from adjacent slopes or atmospheric transport on long distances [5]. Cryoconite may essentially accelerate glacier degradation by reducing the albedo of the glacier due to its dark color [6]. Cryoconite provide an environment for development of diverse microbial community on an uninhabited glacier surface [7]. Estimation of net primary production and respiration on glaciers, which is connected with cryoconite sediments, are comparable with those in freshwater [8], thus, cryoconite can be considered as a carbon sink which influence the carbon cycle. From the other hand, microbial community of cryoconite can play role in colonization of the territory after glacier retreat because of wide metabolic capabilities and due to relatively similar microbial assemblages in sediments and soils [9]. Geochemistry of cryoconite play an important role in regional ecology and properties of microbial community. Cryoconite is considered as a sink of various elements and, therefore, could bring additional nutrients and pollutants to the foothill ecosystems with meltwater during warm period of the year. A few numbers of studies were carried out about determination of trace elements and nutrients in cryoconite and cryoconite derived periglacial soils in mountain regions $[10,11]$. They took place in Tibetan plateau and in Himalaya. These studies indicate that those elements can be either natural or anthropogenic origin, however the importance of long-term transport in accumulation of elements and their impact on ecosystems and human health is significant. 
The Central Caucasus is a vulnerable region which is sensitive to any disturbances and contaminations [12]. The studying of cryoconite and local soils features is necessary to understand the influence of cryoconite material on the terrestrial ecosystems of this mountain region. It is extremely important to understand those properties due to rapid glacier retreat at the Caucasus mountains [13]. The aim of work is to study geochemical and microbiological properties of cryoconite and other supraglacial sediments, sampled from two glaciers of the Central Caucasus and cryoconite derived periglacial soils of Baksan gorge, development of which is based on incoming cryoconite material. To achieve this aim, some goals were set:

1. to investigate physical and chemical parameters of supraglacial sediments and local soils;

2. to study the amount of nutrients in sediments and soils;

3. to define the amount of trace elements in studied materials.

\section{Objects and methods}

The study area is located in the Central Caucasus mountain area, Elbrus district, Kabardino-Balkarian Republic, Russia (Figure 1).

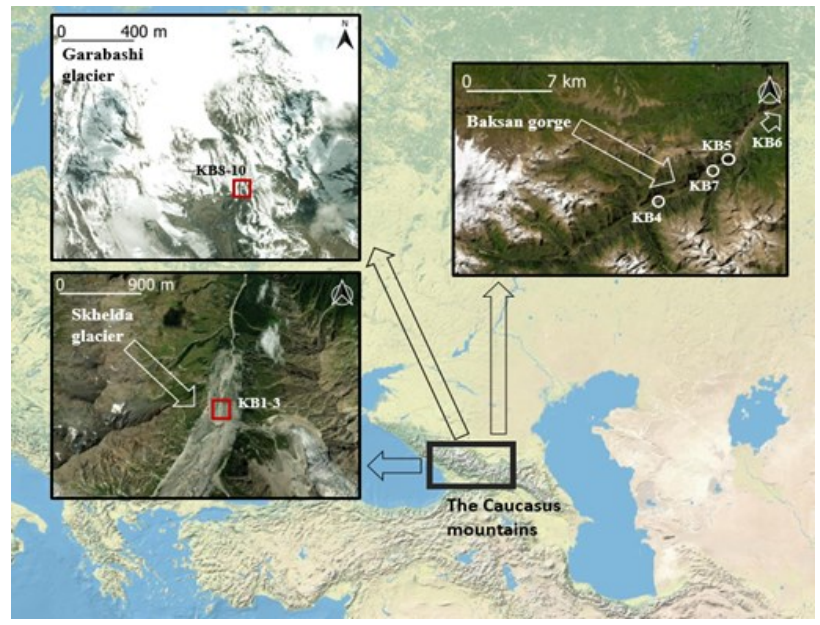

Fig. 1. The study site

The soil-forming rocks of local soils are represented by eluvial-deluvial deposits of limestone, carbonate clays and calcareous sandstones [14]. The average annual temperature in the mountain zone of Elbrus region is $8.05{ }^{\circ} \mathrm{C}$ and in the high-mountain zone is 2.5 ${ }^{\circ} \mathrm{C}[15]$, the amount of precipitation ranges between 660 and $760 \mathrm{~mm} /$ year.

Sampling plots of cryoconite and other sediments are located at the Skhelda glacier (Figure 2) and Garabashi glacier (Figure 3).

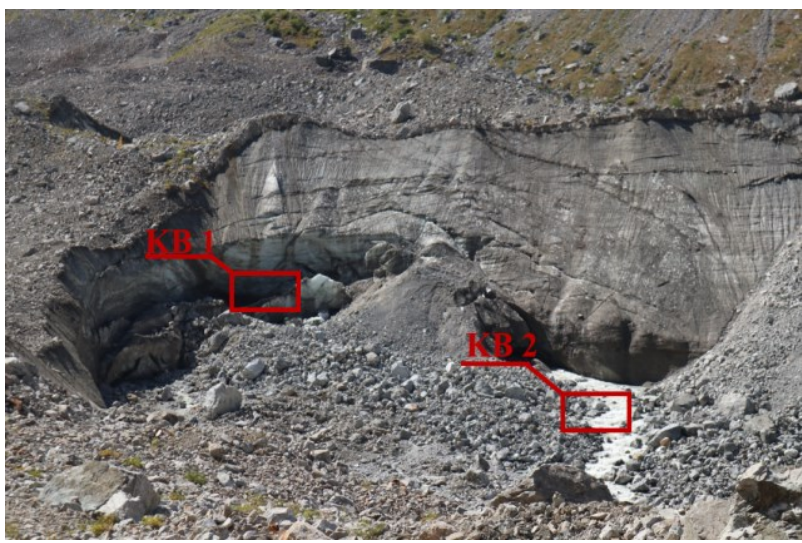

Fig. 2. Sampling plots at the Skhelda glacier

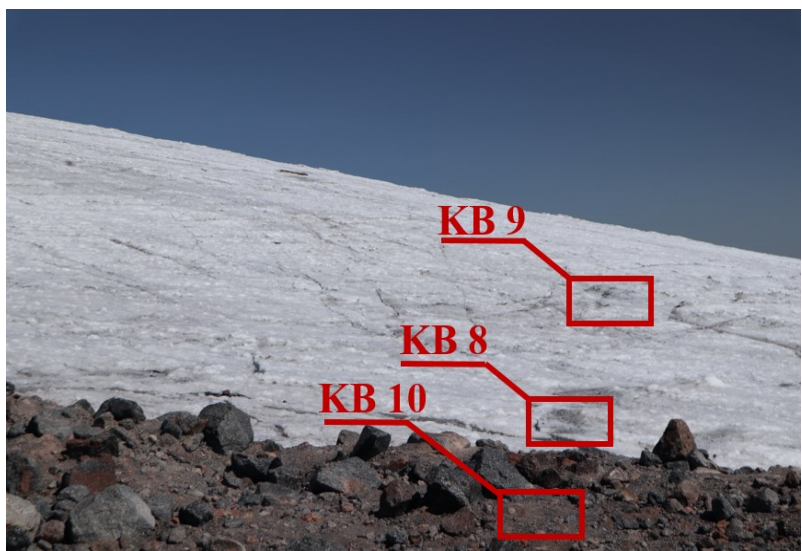

Fig. 3. Sampling plots at the Garabashi glacier

We have considered samples from cryoconite holes, moraine, material that was accumulated in the Baksan gorge during the mudflow in 2019, alluvial material from the debris-covered Skhelda glacier. The Skhelda glacier is located to the southeast of Mount Elbrus, on the border of Russia and Georgia. Its area is about $8 \mathrm{~km}^{2}$ and it feeds the Skhelda river. The Garabashi glacier is located on the southeastern slope of Mount Elbrus. Its length is 4090 meters and its area is about $5 \mathrm{~km}^{2}$. It feeds the Baksan river.

To identify trends in the activity of soil-forming processes occurring in precipitation from the surface of glaciers and compare them, we studied the zonal soils of the Baksan Gorge, they included Entisols (Chestnut soils) (Figure 4) and Chernozem (Figure 5).

The soil classification was performed according to World Reference Base for Soil Resources [16] and Russian Soils Classification System [17].

Description of samples is presented in Table 1.

We considered the following parameters: total organic carbon (TOC) (for understanding the functioning of the global carbon cycle in mountain ecosystems), soil microbiological activity (basal respiration) (indicators of which are directly related to the processes of transformation and stabilization of organic matter of different genesis), actual and exchange acidity of soils $(\mathrm{pH} \mathrm{H} 2 \mathrm{O}, \mathrm{pH} \mathrm{KCl})$, particle size distribution. Total organic carbon (TOC) content was determined by dichromate oxidation-titration method [18]. 


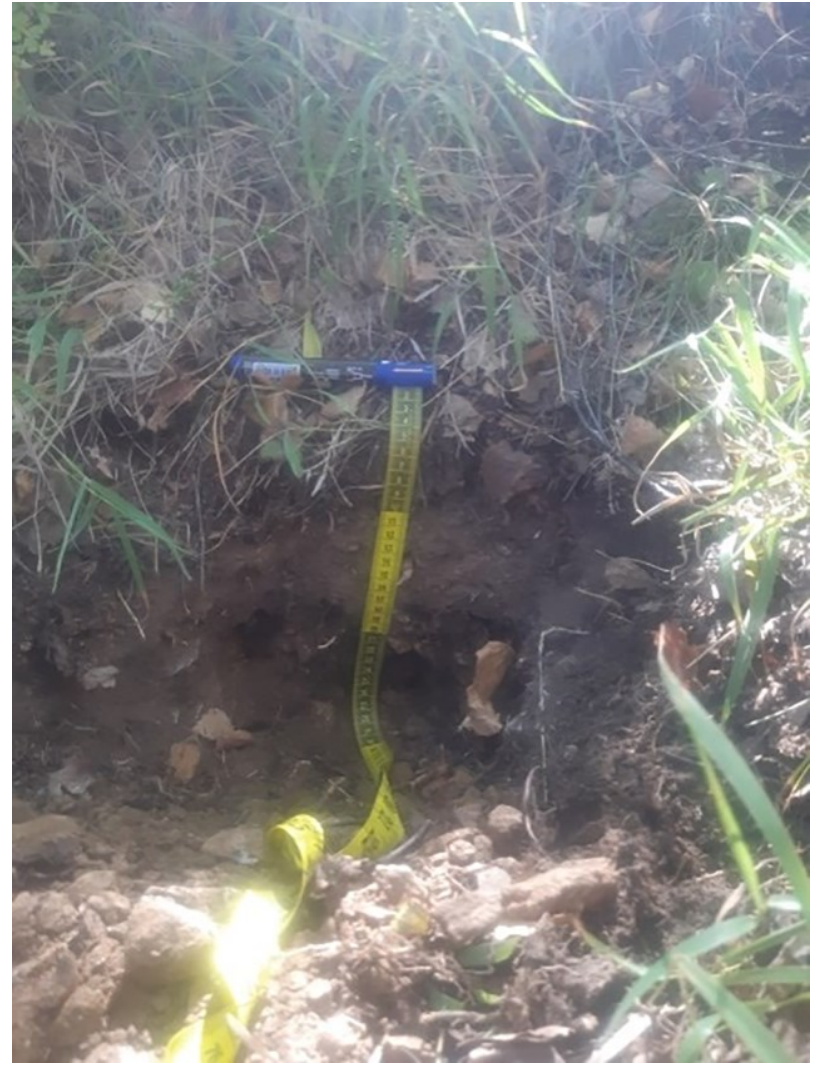

Fig. 4. Soil profile of studied Entisol

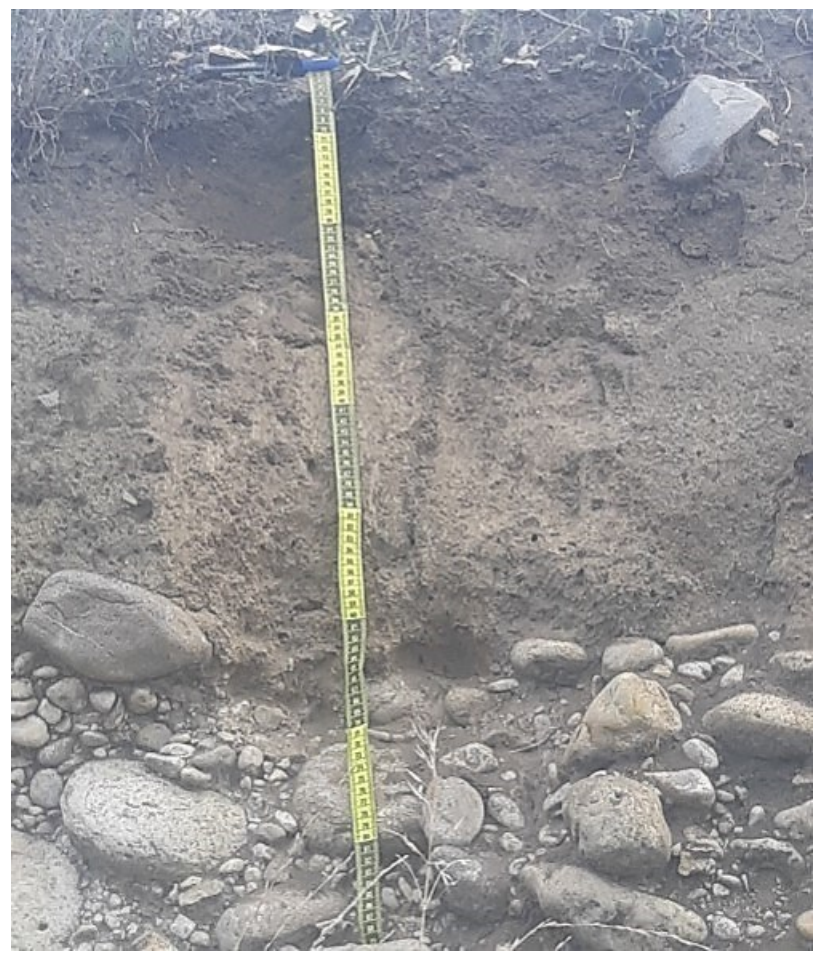

Fig. 5. Soil profile of studied Chernozem

Basal respiration was determined in laboratory incubation experiment. The particle-size distribution analysis was carried out according to the Kachinsky "wet sedimentation" method. The content of nutrients in the cryoconite sediments and soils of the Baksan gorge was determined in accordance with the Russian state standards GOST R 54650-2011 [19] and GOST 26489-
85 [20] which is based on extracting mobile phosphorus $\left(\mathrm{P}_{2} \mathrm{O}_{5}\right)$ and potassium $\left(\mathrm{K}_{2} \mathrm{O}\right)$ compounds from the soil with a hydrochloric acid solution and quantitatively determining the phosphorus and potassium content. Available forms of nitrogen were determined according to ISO 14256-1 [21] which first extracts exchangeable ammonium $\left(\mathrm{NH}_{4}\right)$ from the soil with a potassium chloride solution and then photometrically measuring the colored solution. The analysis of the main pollutants that pose a threat to the life of the population was carried out by photometric method at atomic absorption spectrophotometer Kvant $2 \mathrm{M}$ in accordance with the international standard ISO 11047-1998 [22].

Table 1. Description of study samples

\begin{tabular}{|c|c|c|c|}
\hline Sample & $\begin{array}{c}\text { Description of study } \\
\text { site }\end{array}$ & Horizon & Soil type \\
\hline KB 1 & \multirow{3}{*}{ Skhelda glacier } & Surface & - \\
\hline KB 2 & & Surface & - \\
\hline KB 3 & & Surface & - \\
\hline \multirow{3}{*}{ KB4 } & \multirow{3}{*}{$\begin{array}{c}\text { The right bank of the } \\
\text { Baksan river, in vicinity } \\
\text { of the settlement } \\
\text { Neutrino }\end{array}$} & Oe & \multirow{3}{*}{$\begin{array}{l}\text { Entisol } \\
\text { (Chestnut } \\
\text { soils) }\end{array}$} \\
\hline & & $\mathrm{Ah}$ & \\
\hline & & $\mathrm{A} / \mathrm{C}$ & \\
\hline \multirow{3}{*}{ KB5 } & \multirow{3}{*}{$\begin{array}{c}\text { The left bank of the } \\
\text { Baksan river, in vicinity } \\
\text { of the settlement Upper } \\
\text { Balkania }\end{array}$} & $\mathrm{Ah}$ & \multirow{3}{*}{$\begin{array}{l}\text { Entisol } \\
\text { (Chestnut } \\
\text { soils) }\end{array}$} \\
\hline & & $\mathrm{A} / \mathrm{C}$ & \\
\hline & & $\mathrm{Ck}$ & \\
\hline \multirow{2}{*}{ KB6 } & \multirow{2}{*}{$\begin{array}{l}\text { Elbrus district, in the } \\
\text { vicinity of Kiendele } \\
\text { settlement }\end{array}$} & $\mathrm{Ah}$ & \multirow{2}{*}{ Chernozem } \\
\hline & & $\mathrm{Bk}$ & \\
\hline \multirow{2}{*}{ KB7 } & \multirow{2}{*}{$\begin{array}{c}\text { The right bank of } \\
\text { Baksan river, between } \\
\text { the settlement Upper } \\
\text { Baksan and Tyrnyauz } \\
\text { city }\end{array}$} & $\mathrm{Ch}$ & - \\
\hline & & $\mathrm{C}$ & - \\
\hline KB8 & \multirow{3}{*}{ Garabashi glacier } & Surface & - \\
\hline KB9 & & Surface & - \\
\hline KB10 & & Surface & - \\
\hline
\end{tabular}

All statistical analyses were performed at the program Statistica 12. One-way ANOVA was applied to test the statistical significance of differences between obtained data. Spearman's rank correlation test, which is used in nonparametric methods, was performed to evaluate the relationship between obtained results of measurements.

\section{Results and discussion}

Results of physical and chemical analysis are shown in Table 2 .

The studied cryoconite (as well as alluvial material, moraine and mudflow sediments) are characterized on average by lower values of microbiological activity (basal respiration) than the soils of this region which is due to a suppression of the microbiota under harsh conditions and lack of moisture on the surface of glaciers. 
Table 2. Results of physicochemical analysis of studied samples

\begin{tabular}{|c|c|c|c|c|}
\hline \multirow{2}{*}{ Sample } & $\begin{array}{c}\mathbf{p H} \\
\left(\mathbf{H}_{2} \mathbf{O}\right)\end{array}$ & $\begin{array}{c}\mathbf{p H} \\
\left(\mathbf{C a C l}_{2}\right)\end{array}$ & $\begin{array}{c}\text { Basal } \\
\text { respiration } \\
\left(\mathbf{m g} \mathbf{C O}_{2} / \mathbf{1 0 0} \mathbf{g}\right. \\
\text { *day })\end{array}$ & TOC, $\%$ \\
\hline KB1 & 6.07 & 5.17 & 24.2 & 0.16 \\
\hline KB2 & 6.54 & 6.35 & 11.0 & 0.28 \\
\hline KB3 & 6.45 & 5.96 & 6.6 & 0.11 \\
\hline \multirow{3}{*}{ KB4 } & 6.49 & 5.67 & 39.6 & 2.86 \\
\cline { 2 - 5 } & 6.58 & 5.60 & 39.6 & 1.61 \\
\cline { 2 - 5 } & 6.44 & - & 17.6 & 0.89 \\
\hline \multirow{3}{*}{ KB5 } & 6.90 & 6.05 & 48.4 & 2.44 \\
\cline { 2 - 5 } & 6.98 & 6.06 & 30.8 & 2.15 \\
\cline { 2 - 5 } & 6.98 & 6.30 & 17.6 & 1.37 \\
\hline \multirow{2}{*}{ KB6 } & 7.89 & - & 22.0 & 2.49 \\
\cline { 2 - 5 } & 7.82 & - & 26.4 & 0.68 \\
\hline \multirow{2}{*}{ KB 7 } & 7.24 & - & 17.6 & 0.15 \\
\cline { 2 - 5 } & 6.95 & 6.92 & 17.6 & 0.13 \\
\hline KB8 & 5.84 & 4.45 & 41.8 & 1.41 \\
\hline KB9 & 7.25 & - & 24.2 & 0.29 \\
\hline KB10 & 6.16 & 5.49 & 39.6 & 0.05 \\
\hline
\end{tabular}

The content of total organic carbon in most samples is relatively low, but its amount increases significantly in the studied soils of the periglacial zone due to the accumulation of carbon in the fine earth fraction of the soil under the influence of primary vegetation and arid climate type. Values of the acidity of soil solutions show an essential similarity between the studied cryoconite and soils of the periglacial zone, they vary from slightly acidic to slightly alkaline in both groups, which is associated with the accumulation of carbonates and their presence in the parent rocks. At the same time, the variation of exchange acidity values between cryoconite samples is much higher than in relatively developed soils of the periglacial zone.

Statistically significant difference between values of total organic carbon in sediments and soils is observed according to one-way ANOVA test $(\mathrm{F}=21.28, \mathrm{p}<0.05)$. Reliable correlation (0.51) is observed between values of TOC and basal respiration, according to Spearman's test.

In addition, the density of the solid phase of the studied cryoconites varies in a larger range of values than the density of the studied soils, which is due to the variety of sources of cryoconite materials. However, the analysis of the particle size distribution (Table 3, Figure 6) showed a significant similarity of the studied objects: in almost all samples there is a significant dominance of the sand fraction $(\mathrm{d}=1-0.05 \mathrm{~mm})$. This is due to the low transformation of mineral particles during soil weathering, the main type of weathering is the mechanical destruction of mineral particles. In previous study in Svalbard [23] the particle size distribution of cryoconite sediments was characterized by dominance of fine earth fraction and for subglacial soils by dominance of coarse earth, the content of fine earth fraction was about $60 \%$. In our case this distribution was not so uniform, some cryoconite sediment samples are dominated by coarse earth fraction while this parameter for soils differ between samples. This can be due to different development of cryoconite sediments and soils, another transported material and local factors.

Statistically significant negative correlation $(-0.89)$ is observed between the content of sand and silt in materials.

Table 3. Particle size distribution of studied samples

\begin{tabular}{|c|c|c|c|c|c|c|}
\hline Sample ID & Horizon & $\begin{array}{c}\text { Coarse earth, } \\
\%\end{array}$ & $\begin{array}{c}\text { Fine earth, } \\
\%\end{array}$ & $\begin{array}{c}\text { Sand } \\
(1-0.05 \mathrm{~mm}), \\
\%\end{array}$ & $\begin{array}{c}\text { Silt } \\
(\mathbf{0 . 0 5 - 0 . 0 0 2 m m )}, \\
\text { \% }\end{array}$ & $\begin{array}{c}\text { Clay } \\
(<0.002 \mathrm{~mm}), \\
\%\end{array}$ \\
\hline KB1 & Surface of the glacier & 93.40 & 6.60 & 69.08 & 27.45 & 3.47 \\
\hline KB2 & Surface of the glacier & 14.90 & 85.10 & 75.76 & 23.91 & 0.33 \\
\hline KB3 & Surface of the glacier & 44.00 & 56.00 & 65.80 & 28.86 & 5.34 \\
\hline KB4 & $\mathrm{Oe}$ & 49.50 & 50.50 & 72.52 & 15.09 & 12.39 \\
\hline \multirow{3}{*}{ KB5 } & $\mathrm{Ah}$ & 16.10 & 83.90 & 80.99 & 10.08 & 8.93 \\
\hline & $\mathrm{A} / \mathrm{C}$ & 21.10 & 78.90 & 81.44 & 12.74 & 5.82 \\
\hline & $\mathrm{Ck}$ & 38.10 & 61.90 & 85.12 & 6.16 & 8.72 \\
\hline \multirow{2}{*}{ KB6 } & $\mathrm{Ah}$ & 44.30 & 55.70 & 85.12 & 7.91 & 6.97 \\
\hline & $\mathrm{Bk}$ & 31.20 & 68.80 & 75.30 & 17.09 & 7.61 \\
\hline \multirow{2}{*}{ KB 7} & $\mathrm{Ch}$ & 31.00 & 69.00 & 81.85 & 12.63 & 5.52 \\
\hline & $\mathrm{C}$ & 32.20 & 67.80 & 85.12 & 11.03 & 3.85 \\
\hline KB8 & Surface of the glacier & 12.60 & 87.40 & 29.71 & 56.91 & 14.10 \\
\hline KB9 & Cryoconite over ice & 84.60 & 15.40 & 89.37 & 3.31 & 7.32 \\
\hline KB10 & $\mathrm{C}$ & 46.20 & 53.80 & 84.32 & 13.56 & 2.12 \\
\hline
\end{tabular}




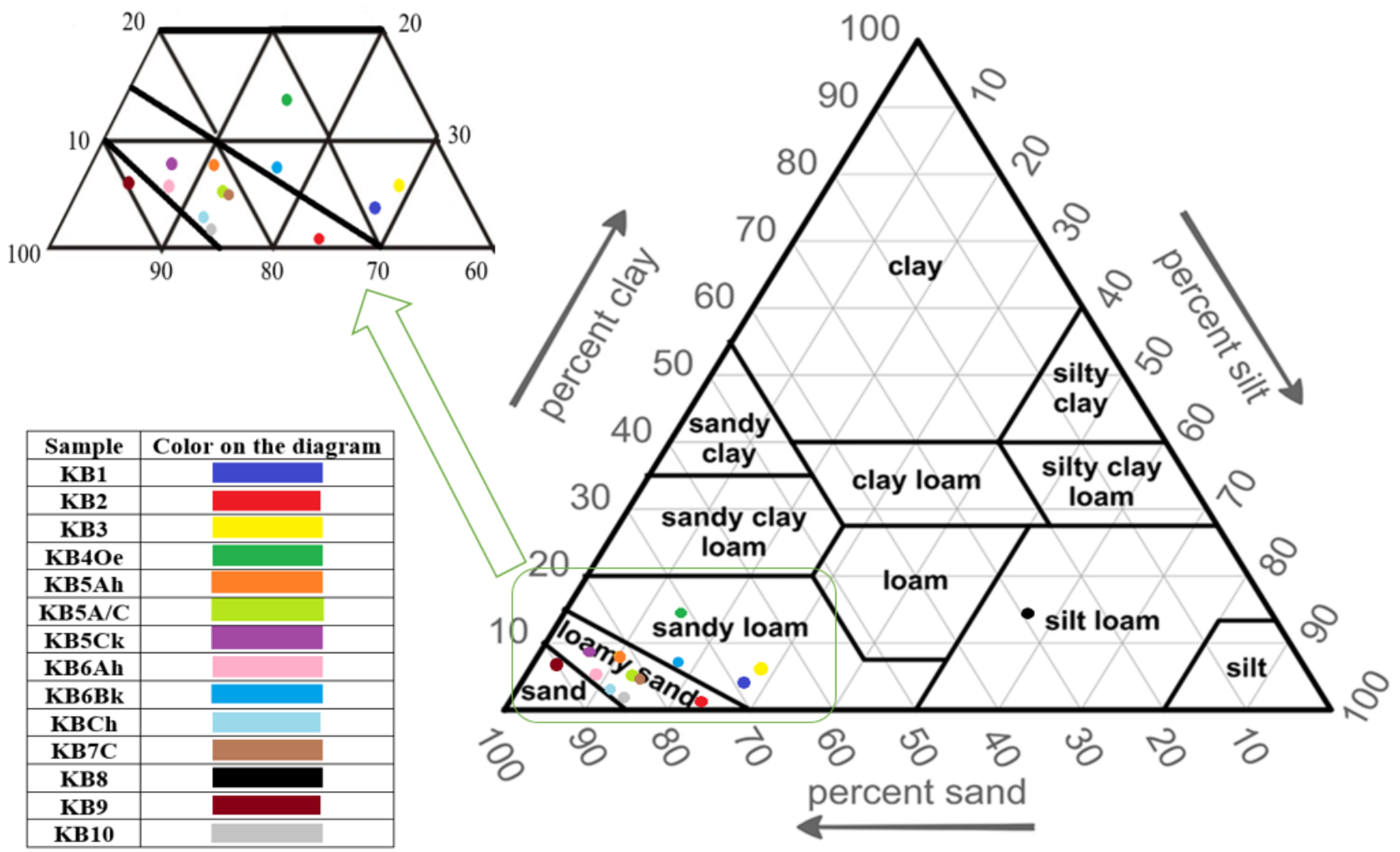

Fig. 6. Particle size distribution of studied materials on the texture triangle.

The study of agrochemical indicators indicates a significant variability between cryoconites, mudflow sediments and soil.

Table 4. Agrochemical features of samples (in $\mathrm{mg} * \mathrm{~kg}$ ).

\begin{tabular}{|c|c|c|c|c|c|}
\hline $\begin{array}{c}\text { Sample } \\
\text { ID }\end{array}$ & Horizon & $\mathbf{P}_{\mathbf{2}} \mathbf{O}_{\mathbf{5}}$ & $\mathbf{K}_{\mathbf{2}} \mathbf{O}$ & $\mathbf{N}^{-\mathbf{N H}_{\mathbf{4}}}$ & $\mathbf{N}-\mathbf{N O}_{\mathbf{3}}$ \\
\hline \multirow{2}{*}{ KB 1 } & $\begin{array}{c}\text { Surface of } \\
\text { the glacier }\end{array}$ & 411 & 29 & 2.7 & 0 \\
\hline \multirow{2}{*}{ KB 2 } & $\begin{array}{c}\text { Surface of } \\
\text { the glacier }\end{array}$ & 412 & 41 & 3.5 & 0 \\
\hline \multirow{2}{*}{ KB 3 } & $\begin{array}{c}\text { Surface of } \\
\text { the glacier }\end{array}$ & 241 & 26 & 3.2 & 0 \\
\hline \multirow{2}{*}{ KB4 } & Oe & 116 & 476 & 18.8 & 0.4 \\
\cline { 2 - 6 } & Ah & 145 & 313 & 14.2 & 0.1 \\
\cline { 2 - 6 } & A/C & 178 & 221 & 14.2 & 0.4 \\
\hline \multirow{2}{*}{ KB5 } & Ah & 366 & 279 & 6.7 & 6.3 \\
\cline { 2 - 6 } & Ck & 317 & 236 & 5.7 & 0 \\
\hline \multirow{2}{*}{ KB6 } & Ah & 27 & 55 & 3.6 & 4.4 \\
\cline { 2 - 6 } & Bk & 25 & 41 & 0.7 & 77.2 \\
\hline \multirow{2}{*}{ KB7 } & Ch & 402 & 43 & 2.9 & 0.6 \\
\cline { 2 - 6 } & C & 310 & 43 & 2.5 & 0 \\
\hline \multirow{2}{*}{ KB8 } & $\begin{array}{c}\text { Surface of } \\
\text { the glacier }\end{array}$ & 394 & 298 & 222.0 & 0.1 \\
\hline \multirow{2}{*}{ KB9 } & $\begin{array}{c}\text { Cryoconite } \\
\text { over ice }\end{array}$ & 304 & 260 & 247.0 & 0 \\
\hline KB10 & $\mathrm{C}$ & 557 & 53 & 14.6 & 0 \\
\hline
\end{tabular}

High values of mobile phosphorus content are observed in cryoconites from both glaciers, alluvial material and mudflow deposits under the vegetation cover. The minimum phosphorus content was recorded in the studied Chernozems $(25 \mathrm{mg} * \mathrm{~kg})$. Differences of phosphorus content in soils and sediments are statistically reliable $(\mathrm{F}=13.38, \mathrm{p}<0.05)$. It happens due to presence of plants, covering soils, which uptake phosphorus. The high content of mobile potassium is characteristic of cryoconites from the Garabashi glacier and Chestnut soils, its values are essentially lower in sediments from the Skhelda Glacier and all other studied materials.

A high content of ammonium nitrogen, in comparison with other samples, is noted in cryoconites from the Garabashi glacier (up to $247.0 \mathrm{mg} * \mathrm{~kg}$ ). The values of nitrate nitrogen are highest in Chernozems (77.2 $\mathrm{mg}^{*} \mathrm{~kg}$ ), its lower content is typical for chestnut soils and mudflow material without vegetation, while zero values are noted in alluvial and moraine sediments, as well as in most cryoconite samples. According to Spearman's rank correlation, statistically significant relationship (0.79) is observed between the content of potassium and $\mathrm{N}-\mathrm{NH}_{4}$.

All this indicates a relatively high microbiological activity of cryoconites from the Garabashi glacier and their high nutrient enrichment, which is comparable to the soils of this region, as well as the correspondence of the poverty of materials from the Skhelda glacier. Cryoconites are natural local depots for nutrients that are brought here by means of an aeolian type of accumulation. The formation of such closed ecosystems 
in cracks and holes on the surface of glaciers leads to the accumulation of mineral particles enriched with nutrients, the accumulation of organic and inorganic (black) carbon. Being in the composition of cryobytes, this material is able to accumulate and in the process of deglaciation or catastrophic events (mudflows) can be released and accumulated in the periglacial zone. Thus, a radical change in the natural ecosystem of the periglacial zone can occur.

In general, soils and other materials under study are characterized by a low level of trace elements content (Table 5). The highest content of trace elements, with the exception of copper, was found in one of the cryoconite samples from the Garabashi glacier, while the corresponding values in the other sample are significantly reduced and are comparable to the studied Chernozems. Among the studied soils, chestnut soils are the most polluted, especially with copper and zinc, while chernozems tend to have less accumulation of trace elements. In other samples, essentially lower concentrations of heavy metals are noted, but in most of them the zinc content, compared with other elements, is high. All of the above is explained by the high level of anthropogenic load on the Garabashi glacier and various sources of pollution in this region.

Statistically reliable differences between content of trace elements in studied sediments and soils are observed for $\mathrm{Cu}(\mathrm{F}=6.36, \mathrm{p}<0.05)$ and $\mathrm{Zn}(\mathrm{F}=9.94$, $\mathrm{p}<0.05$ ). Significant relationships are observed between all trace elements, with the exception of $\mathrm{Cd}$.

The data obtained indicate both the difference between the studied materials from glaciers and the soils, and their probable influence on soil formation in this region. In addition, the data obtained indicate a different level of heavy metal contamination of the two glaciers under study and two different types of soils, which is associated with different sources of allochthonous material and different degrees of their development. To the Elbrus region, dust is transferred by air masses originating from Mesopotamia and Northern Africa [24]. Chemical analysis which was conducted in this study shows the accumulation of nutrients, particularly nitrates, ammonium and sulfates in the dust due to agricultural activities in Mesopotamia. According to our results, cryoconite sediments from the Garabashi glacier are highly enriched with $\mathrm{K}_{2} \mathrm{O}$ and $\mathrm{N}^{-N_{4}}$ (up to 247 $\mathrm{mg} * \mathrm{~kg}$ ). It cannot be explained only by long-distance transfer because values of nitrate nitrogen are much lower at sediments on the Skhelda glacier (max. 3.5 mg*kg). Thus, its content also depends on autochthonous sources of materials what is related to anthropogenic activities. Research of trace elements content in this dust revealed high values of $\mathrm{Cu}, \mathrm{Zn}$ and $\mathrm{Cd}$ which authors associate with high background values in mentioned regions and influence of anthropogenic emissions. Our study shows that both of this processes affect the pollution status of cryoconite. Higher than for other elements values of copper, nickel and, especially, zinc are found at sediments on mostly uncontaminated Skhelda glacier, indicating their transfer from other regions.

Moreover, the content of copper, lead, zinc and nickel is much higher at cryoconite from the Garabashi glacier which cannot be explained by allochtonous origin. Anthropogenic activities, which are connected with tourism, construction and transport, are strongly pronounced at and nearby to the Garabashi glacier. This in turn leads to higher amount of emissions, deposition of them on the glacier and accumulation in cryoconite sediments, in our case up to high pollution level.

Table 5. Trace elements content in studied materials (in $\mathrm{mg}^{*} \mathrm{~kg}$ ).

\begin{tabular}{|c|c|c|c|c|c|c|}
\hline Sample ID & Horizon & Cu & Pb & Zn & Ni & Cd \\
\hline KB 1 & Surface of the glacier & 2.84 & $<0.01$ & 20.00 & 8.42 & $<0.005$ \\
\hline KB 2 & Surface of the glacier & 2.36 & $<0.01$ & 13.40 & 5.58 & $<0.005$ \\
\hline \multirow{2}{*}{ KB 3 } & Surface of the glacier & 3.94 & 0.21 & 18.40 & 6.93 & $<0.005$ \\
\hline \multirow{2}{*}{ KB4 } & Oe & 12.00 & 13.70 & 52.10 & 18.10 & $<0.005$ \\
\cline { 2 - 7 } & Ah & 12.80 & 15.20 & 52.70 & 19.90 & $<0.005$ \\
\hline \multirow{3}{*}{ KB5 } & A/C & 22.50 & 17.00 & 60.50 & 25.40 & $<0.005$ \\
\cline { 2 - 7 } & Ah & 10.40 & 5.53 & 56.40 & 15.50 & 0.05 \\
\cline { 2 - 7 } & A/C & 9.72 & 3.68 & 50.50 & 14.00 & $<0.005$ \\
\hline \multirow{2}{*}{ KB6 } & Ah & 7.11 & 5.21 & 35.10 & 15.20 & 0.03 \\
\cline { 2 - 7 } & Bk & 5.73 & 4.20 & 30.30 & 13.10 & 0.04 \\
\hline \multirow{2}{*}{ KB7 } & Ch & 2.57 & 1.89 & 27.10 & 8.21 & 0.01 \\
\cline { 2 - 7 } & C & 1.90 & 1.99 & 29.20 & 9.10 & 0.02 \\
\hline KB8 & Surface of the glacier & 16.70 & 30.20 & 62.00 & 38.90 & 0.13 \\
\hline KB9 & Cryoconite over ice & 6.92 & 17.10 & 35.50 & 15.90 & 0.05 \\
\hline KB10 & C & 0.33 & 3.48 & 1.05 & $<0.005$ \\
\hline
\end{tabular}


Cryoconite sediments in Elbrus region acts as a sink of nutrients and trace elements in the areas with high anthropogenic pressure (Garabashi glacier) and show a low degree of pollution in background areas with low anthropogenic activity (Skhelda glacier). Previous study of soils in the Caucasus region further from glaciers [25] indicated higher content of ammonium nitrogen (29.7$60.9 \mathrm{mg}^{*} \mathrm{~kg}$ ) than in soils from our study, but still it is much lower than in cryoconite sediments from the Garabashi glacier, which proves the theory that cryoconite could be a source of nutrients in mountain ecosystem.

Transfer of sediments affects the pollution status of soils at the nearest foothill areas, where in our case the concentrations of some trace elements show mostly moderate contamination, decreasing when moving away from the glaciers. It was noted [26] that the highest concentration of $\mathrm{Cu}$ in water in this region was found in the mouth of the Baksan river and this trace element is accumulated downstream in Entisols. Our results revealed that KB4 study point, which is the nearest to the Garabashi glacier, shows the highest contamination level among soils while it decreases at more remote KB5 study point. Chernozems, as the most remote study material from the glaciers, characterized by low degree of contamination for all trace elements, except of zinc. At the same time, studied Entisols have the favorable conditions for transportation of $\mathrm{Cu}$ and $\mathrm{Ni}$ from the soil profile [27] which indicates that those trace elements will not only influence adjacent territories but also will have impact on landscape-geochemical process through long-term migration.

\section{Conclusions}

During conducted research it was revealed that regarding physicochemical features, studied materials mostly differs in terms of total organic carbon content due to accumulation of it under the influence of vegetation cover. Microbiological activity is observed in each study sample, in case of KB8 cryoconite and KB10 moraine deposits from Garabashi glacier it is comparable with those in local Entisols. Most materials are dominated with sand in their texture with the exception of KB8 cryoconite sample where predominance of silt fraction is observed which also indicates the role of incoming material in development of these sediments.

Content of potassium and available nitrogen is significantly higher in cryoconite at Garabashi glacier than in those at Skhelda glacier, indicating various sources of material and impact of anthropogenic activities. The accumulation of trace elements $(\mathrm{Cu}, \mathrm{Pb}$, $\mathrm{Zn}, \mathrm{Ni}, \mathrm{Cd}$ ) in cryoconite sediments is observed mostly at Garabashi glacier where their content is comparable or even higher than in local soils.

The data obtained indicate both the difference between the studied materials from glaciers and the soils, and their probable influence on soil formation in this region. Moreover, data obtained indicated a different level of trace elements contamination of the two glaciers under study and two different types of soils, which is associated with different sources of allochthonous material and different degrees of their development.

This work is supported by the Russian Foundation for Basic Research, project No. 19-05-50107.

\section{References}

1. A.E. Nordenskjold, Geol. Mag. D 2, 157-162 (1875)

2. S. Adhikary, M. Nakawo, K. Seko, B. Shakya, IAHS publ. E 264, 43-52 (2000)

3. B. Di Mauro, G. Baccolo, R. Garzonio, C. Giardiono, D. Massabo, A. Piazzalunga, M. Rossini, R. Colombo, The Cryosphere. E 11, 2393-2409 (2017)

4. A. Hodson, A.M. Anesio, M. Tranter, A. Fountain, M. Osborn, J. Priscu, J. Layborn-Parry, B. Sattler, Glacial ecosystems. Ecol. Mon. E 78, 41-67 (2008)

5. K. Zawierucha, G. Baccolo, B. Di Mauro, A. Nawrot, W. Szczucinski, E. Kalinska, Polar Sc. E 22, 100482 (2019)

6. A. Humbert, L. Schröder, T. Schultz, R. Müller, N. Neckel, V. Helm, R. Zindler, K. Eleftheriadis, R. Salzano, R. Salvatori, Rem. Sens. E 12, 3793 (2020)

7. A. Edwards, J.A. Pachebat, M. Swain, M. Hegarty, A.J. Hodson, T.D. Irvine-Fynn, S. M. Rassner, B. Sattler, Env. Res. Lett. E 8, 035003 (2013)

8. A.M. Anesio, A.J. Hodson, A. Fritz, R. Psenner, B. Sattler, Glob. Change Biol. E 15, 955-960 (2009)

9. A. Sanyal, R. Antony, P. Ganesan, M. Thamban, Antonie van Leeuwenhoek. E 113, 2243-2258 (2020)

10. S.M. Singh, K. Avinash, P. Sharma, R.U. Mulik, A.K. Upadhyay, R. Ravindra, Geosc. Front. E 8 , 1339-1347 (2017)

11. X. Jiao, Z. Dong, S. Kang, Y. Li, C. Jiang, M. Rostami, Ecotoxicol. and Env. Safety. E 207, 111$228(2021)$

12. D.I. Moshenko, A.A. Kuzina, S.I. Kolesnikov, Sust. Dev. of Mount. Terr. E 12, 76-87 (2020)

13. C. Stokes, V. Popovnin, A. Aleynikov, S. Gurney, M. Shahgedanova, Ann. of Glaciol. E 46, 195-203 (2007)

14. Soils of the Kabardino-Balkarian Autonomous Soviet Socialist Republic and recommendations for their use (State Design Institute for Land Management SevKavNIIgiprozem, 1984)

15. A.A. Tashilova, B.A. Ashabokov, L.A. Kesheva, N.V. Teunova, Climate. E 7, 11 (2019)

16. World Reference Base for Soil Resources. International soil classification system for naming soils and creating legends for soil maps. World Soil Resources Reports E. 106, 181 (2014)17. Classification and diagnostics of soils of Russia. Smolensk: Oykumena, 182 (2008)

17. Classification and diagnostics of soils of Russia. Smolensk: Oykumena, 342 (2004)

18. A. Walkley. Soil Sc. E 63, 251-264 (1947) 
19. Soils. Determination of mobile phosphorus and potassium compounds by Kirsanov method modified by ClNAO (GOST R 54650-2011)

20. Soils. Determination of exchangeable ammonium by CINAO method (GOST 26489-85)

21. Soil quality - Determination of nitrate, nitrite and ammonium in field-moist soils by extraction with potassium chloride solution - Part 1: Manual method (ISO 14256-1)

22. Soil quality - Determination of cadmium, chromium, cobalt, copper, lead, manganese, nickel and zinc Flame and electrothermal atomic absorption spectrometric methods (ISO 11047-1998)

23. K. Kastovska, J. Elster, M. Stibal, H. Santruckova, Microb. Ecol. E 50, 396 (2005)

24. S. Kutuzov, V. Mikhalenko, M. Shahgedanova, P. Ginot, A. Kozachek, T. Kuderina, I. Lavrentiev, G. Popov, Ice and Snow. E 54, 5-15 (2015)

25. M. Makarov, V. Onipchenko, A. Tiunov, T. Malysheva, M. Kadulin, Euras. Soil Sc. E 53, 11731181.

26. V. Ermakov, S. Tyutikov, A. Degtyarev, V. Danilova, U. Gulyaeva, D. Dogadkin, Geochem. Intern. E 58, 1097-1109 (2020)

27. A.V. Khoroshev, Ser. Geographich. E 6, 77-82 (2001) 